\title{
Orientasi Nilai Budaya Masyarakat Nias dalam Maena pada Upacara Falöwa
}

\author{
Nias Society's Cultural Value Orientation in Maena at the Falöwa Ceremony
}

\author{
Titian Berkat Gea \\ Pascasarjana Universitas Sanata Dharma Yogyakarta \\ Corresponding email: titiangea1991@gmail.com
}

Received: 12 April 2021 Accepted: 17 September 2021 Published: 7 November 2021

\begin{abstract}
This study aims to describe the orientation of Nias cultural values in the lyrics of the maena at the falöwa traditional ceremony in Gunungsitoli. The research was conducted using a qualitative method with an anthropolinguistic approach. The data in this study is a snippet of the lyrics of the maena at the traditional falöwa (wedding) ceremony, either spoken orally or a collection of written lyrics. Primary data sources are the results of interviews with informants and recordings of playing. The secondary data source is the maena lyric text in the book "Maena Nias - Means of Delivering Messages and Life Stories of the Nias Society," published by the Nias Heritage Museum, 2018. Data were collected using observation and interview methods. The observation method is carried out using the tapping and nonparticipation and the recording techniques as further techniques. The interview method uses direct interview techniques. Then, the data were analyzed in stages: (1) data reduction, (2) data presentation, and (3) making conclusions/verification. In the analysis process, the researcher also validated the data by applying data triangulation. The triangulation used in this study is source triangulation. The study results concluded that, first, the society of Nias interprets the nature of life as something that needs to be fought for. Second, the society of Nias views that the nature of the work can increase the position and honor of humans in their environment. Third, Nias society view that humans are influenced by space and time. Fourth, Nias society views the importance of harmonious relations between humans and their natural surroundings. Fifth, Nias society upholds human relations with each other.
\end{abstract}

Keywords: society, language, cultural value orientation, maena lyrics, anthropolinguistics

Abstrak: Penelitian ini bertujuan untuk mendeskripsikan orientasi nilai budaya masyarakat Nias dalam syair maena pada upacara adat falöwa di Gunungsitoli. Penelitian dilakukan menggunakan metode kualitatif dengan pendekatan antropolinguistik. Adapun data dalam penelitian ini adalah cuplikan syair maena pada upacara adat falöwa (pernikahan) baik dituturkan secara lisan maupun kumpulan syair secara tertulis. Sumber data primer berupa hasil wawancara dengan informan dan rekaman maena. Sumber data sekunder yaitu teks syair maena dalam buku "Maena Nias - Sarana Penyampaian Pesan dan Kisah Hidup Orang Nias" yang diterbitkan oleh Museum Pusaka Nias, tahun 2018. Data dikumpulkan dengan menggunakan metode simak dan cakap. Metode simak dilakukan dengan teknik sadap dan teknik simak libat bebas cakap dan teknik rekaman sebagai teknik lanjutannya. Sedangkan metode cakap dilakukan dengan menggunakan teknik cakap semuka. Kemudian, data dianalisis dengan tahapan: 1) reduksi data, 2)penyajian data, dan 3) penarikan kesimpulan/verifikasi. Dalam proses analisis, peneliti juga melakukan validasi data dengan menerapkan triangulasi data. Triangulasi yang digunakan dalam penelitian ini adalah triangulasi sumber. Hasil penelitian menunjukkan bahwa: (1) masyarakat Nias memaknai hakikat hidup sebagai sesuatu hal yang perlu diperjuangkan; (2) masyarakat Nias memandang hakikat dari karya dapat meningkatkan kedudukan dan kehormatan manusia dalam lingkungannya; (3) masyarakat Nias memandang bahwa manusia dipengaruhi oleh ruang dan waktu; (4) masyarakat Nias memandang pentingnya keselarasan hubungan manusia dan alam sekitarnya; dan (5) masyarakat Nias menjunjung tinggi hubungan manusia dengan sesamanya.

Kata kunci: masyarakat, bahasa, orientasi nilai budaya, maena, antropolinguistik

To cite this article:

Gea, T. B. (2021). Orientasi Nilai Budaya Masyarakat Nias dalam Maena pada Upacara Falöwa. Diglosia: Jurnal Kajian Bahasa, Sastra, dan Pengajarannya, 4(4), 487-498. https://doi.org/10.30872/diglosia.v4i4.215 


\section{A. PENDAHULUAN}

Masyarakat bertumbuh dari kebiasaan-kebiasaan yang muncul dalam interaksi antar individu yang kemudian secara turun temurun dilakukan oleh setiap anggota kelompok masyarakatnya. Koentjaraningrat (2002:14) mendefinisikan masyarakat sebagai sekumpulan manusia yang saling "bergaul" atau saling berinteraksi. Interaksi yang berlangsung dalam masyarakat merupakan interaksi yang berkelanjutan atau berlangsung turun-temurun. Dalam hubungan tersebut terbentuk berbagai pengalaman, kepercayaan, pemahaman, pandangan hidup yang seterusnya dijadikan sebagai tata aturan yang harus dijalani bersama. Sejalan dengan pernyataan tersebut, Durkheim berpendapat bahwa masyarakat menjadi wadah yang paling tepat untuk kehidupan bersama antar manusia (Muhni, 1994). Masyarakat melahirkan sebuah budaya dan adat istiadat serta hukum untuk diketahui dan dijalani oleh setiap anggota masyarakatnya sebagai bentuk usaha untuk mempertahankan keutuhan kelompok serta mencapai tujuan bersama.

Kebudayaan terdiri atas daya dari budi yang berupa cipta, karsa dan rasa yang hanya dapat berkembang secara berkelanjutan dan turun temurun lewat media komunikasi yang digunakan oleh masyarakatnya yaitu bahasa (Wardaugh, 2006, hal.21). Bahasa dan budaya dapat dikatakan sebagai komponen yang saling terkait dan memiliki fungsi yang bertaut. Bahasa dan budaya menurut Levi-Strauss (1963) memiliki hubungan yang erat di mana bahasa yang digunakan oleh seseorang atau kelompok tertentu merupakan refleksi dari kebudayaan masyarakat tersebut. Melalui bahasa akan menunjukkan identitas kelompok termasuk budayanya (Mujib, 2009, hal. 15), seperti jargon yang mengatakan "bahasa menunjukkan bangsa", yang juga dimaknai bahwa bahasa menunjukkan budaya dan asal usul seseorang.

Suku Nias merupakan sebutan yang diberikan kepada penduduk asli yang menghuni Pulau Nias. Kepulauan Nias terletak di lepas pantai barat Samudera Hindia yang memiliki pulau-pulau kecil di sekitarnya. Keberadaan masyarakat Nias yang hidup terpisah dari wilayah suku lainnya di Indonesia menghasilkan tradisi khas yang lahir di masyarakatnya. Hingga saat ini, masyarakat Nias masih menjunjung tinggi budaya dan adat istiadat yang diturunkan oleh nenek moyang suku Nias. Hal tersebut terlihat dari berbagai acara adat yang diadakan oleh masyarakat Nias yang masih kental dengan aturan-aturan adat dan tradisi atau ritual.

Manusia sebagai bagian dari masyarakat sosial tentu akan menjalani berbagai siklus kehidupan yang tidak lepas dari lingkup budaya dan tradisi yang berlaku di sekitarnya. Setiap masyarakat budaya akan menjalani sebuah tradisi sebagai bentuk loyalitas atas aturan-aturan yang telah ditetapkan oleh para leluhurnya. Salah satu siklus kehidupan manusia yang sangat sarat dengan tradisi adalah pernikahan. Dalam budaya Nias, adat upacara pernikahan telah diatur di dalam fondrakö. Fondrakö merupakan sumber hukum yang mengatur tatanan kehidupan masyarakat Nias, baik secara individu maupun dalam kelompok. Bagi masyarakat Ono Niha (sebutan untuk masyarakat suku Nias), fondrakö menjadi landasan dalam menjalani kehidupan, mengolah masalah dan mengambil keputusan atas persoalan yang sedang dihadapi (Mendrőfa, 1981, hal. 11). Maka, dalam menjalani upacara pernikahan masyarakat Nias akan menjalani syarat dan aturan yang telah ditetapkan dalam fondrakö.

Pada upacara falöwa ditemukan berbagai rangkaian acara yang melibatkan tuturan tradisi lisan seperti böli hae, hendri-hendri, dan tari maena. Beberapa tradisi lisan yang dituturkan merupakan satu kesatuan yang tidak terpisahkan dalam 
upacara falöwa. Tradisi lisan yang akan menjadi fokus peneliti dalam tulisan ini adalah maena. Maena merupakan tarian yang melibatkan banyak orang sehingga tarian ini dapat dikategorikan sebagai tarian kolosal. Maena menjadi salah satu tradisi khas dan unik yang dilakukan masyarakat Nias pada saat berlangsungnya falöwa. Maena akan ditarikan oleh orang-orang yang ada dalam pesta tersebut, baik pihak dome (pihak laki-laki) maupun pihak sowatö (tuan rumah/pihak perempuan). Maena ditarikan dengan pola gerakan sederhana dan diiringi dengan nada yang penuh semangat. Lagu akan dipimpin oleh penutur syair maena (sanutunö maena), sedangkan peserta maena akan menyambutnya dengan menyanyikan bagian refrain dari lagu maena. Tari maena sangat menuntut kebersamaan dan kekompakan dalam gerakan dan menuturkan syairnya. Hal tersebut menunjukkan bahwa maena tidak hanya sekedar hiburan atau pertunjukkan melainkan bertujuan untuk membangun nilai-nilai kebersamaan, kerja sama dan persatuan di antara kedua pihak keluarga (Zaluchu, 2020, hal. 137). Tetapi, yang terpenting dalam maena adalah syair yang dituturkan (Hämmerle et al., 2018). Syair yang dituturkan dalam maena tidak hanya sekedar kata-kata tanpa makna, syair maena terdiri atas kata-kata puitis yang memiliki pesan mendalam yang ingin disampaikan kepada pihak-pihak tertentu, seperti pihak sowatö, dome atau pihak pengantin perempuan dan laki-laki.

Maena adalah salah satu tradisi lisan yang masih ditampilkan pada kegiatan atau upacara adat Nias. Namun, perkembangan zaman yang semakin modern telah memberi pengaruh terhadap keberadaan dan eksistensi tradisi lisan dalam masyarakat Nias. Maena yang pada hakikatnya merupakan syair-syair berbahasa Nias saat ini telah mengalami interferensi bahasa Indonesia. Kenyataan tersebut memberikan dampak negatif terhadap kebertahanan bahasa Nias. Interferensi bahasa Indonesia terhadap syair maena semakin menutup wawasan masyarakat Nias terutama generasi muda terhadap kosa kata bahasa daerahnya sendiri. Terjadinya percampuran bahasa Indonesia dan bahasa Nias dalam syair maena dilatarbelakangi oleh keberadaan bahasa Nias yang mulai jarang digunakan oleh masyarakat Nias yang ada di wilayah Kota Gunungsitoli.

Masyarakat penduduk Nias merupakan masyarakat plural karena pulau ini tidak hanya terdiri dari suku Nias, tetapi juga dihuni oleh masyarakat suku lain (pendatang). Keberadaan suku lain dilatarbelakangi dari berbagai kepentingan seperti perdagangan (Suwartiningsih \& Samiyono, 2014, hal. 238). Kota Gunungsitoli merupakan pemekaran dari Kabupaten Nias berdasarkan UndangUndang Republik Indonesia Nomor 47 Tahun 2008 yang terdiri atas 6 (enam) kecamatan, yaitu Gunungsitoli, Gunungsitoli Utara, Gunungsitoli Selatan, Gunungsitoli Barat, Gunungsitoli Alo'oa dan Gunungsitoli Idanoi. Kota Gunungsitoli merupakan wilayah yang lebih maju dalam berbagai aspek dibanding daerah atau kabupaten lainnya yang ada di Pulau Nias, selain itu wilayah ini juga dihuni oleh masyarakat dari berbagai suku pendatang seperti suku Batak, Minang, dan Tionghoa, sehingga bahasa Indonesia menjadi bahasa pilihan dalam berkomunikasi. Hal tersebut berdampak pada syair maena yang saat ini digubah secara bebas oleh para penuturnya masing-masing. Gubahan yang dilakukan secara bebas oleh masyarakat Nias memberi berbagai dampak yang signifikan seperti semakin besarnya peluang bahasa lain dimuat dalam syair maena dan resiko terbesarnya dapat menghilangkan nilai-nilai luhur masyarakat Nias yang terkandung dalam syair. Keadaan tersebut terjadi dilatarbelakangi oleh kenyataan bahwa masyarakat Nias saat ini masih belum memahami tentang hakikat maena 
sesungguhnya sehingga menyebabkan syair-syair maena dianggap tidak lebih dari sekedar nyanyian hiburan. Keadaan tersebut tidak bisa dibiarkan, maena sebagai warisan leluhur perlu dikembalikan pada posisi dan fungsinya yang sesungguhnya yaitu sebagai pengarah dan penuntun masyarakatnya dalam memaknai dan menjalankan kehidupan.

Nilai budaya merupakan warisan leluhur yang memiliki peranan penting dalam mengatur kehidupan anggota kelompoknya. Nilai sebagai sebuah sistem dalam masyarakat yang berfungsi sebagai pedoman atas tingkah laku manusia. Sistem nilai budaya dalam masyarakat dibuat berdasarkan pengalam hidup dan menyangkut permasalahan pokok hidup manusia, sehingga sulit diganti atau diubah dalam waktu yang singkat.

Keragaman wilayah, kelompok, dan pengalaman hidup menghasilkan nilainilai yang berbeda-beda, bahkan mungkin saja bertentangan dengan nilai yang dianut kelompok lain. Setiap suku bangsa memiliki orientasi nilai budayanya sendiri, hal ini dikarenakan nilai budaya merupakan rangkaian konsep yang berkaitan dengan perilaku atau tingkah laku antar manusia, manusia dengan alam, dan segala sesuatu yang diingini maupun yang tidak diingini dalam konteks lingkungan masyarakatnya (Kluckhohn \& Strodtbeck, 1961). Sedangkan nilai-nilai dalam sebuah kelompok masyarakat tertentu saling berkaitan antara yang satu dengan lainnya. Keterkaitan antar nilai-nilai tersebut membentuk sistem nilai yang dipercaya dan digunakan oleh anggota kelompoknya sebagai pedoman terhadap konsep ideal dalam menjalani kebudayaan. Kluckhohn (Kluckhohn \& Strodtbeck, 1961) mengklasifikasi orientasi nilai budaya ke dalam lima masalah dasar yang muncul dalam kehidupan manusia, yaitu: a) masalah hakikat hidup, b) masalah hakikat dari karya manusia, c) masalah hakikat dari kedudukan manusia dalam ruang waktu, d) masalah hakikat dari hubungan manusia dengan alam sekitarnya dan e) masalah hakikat dari hubungan manusia dengan sesamanya.

Nilai-nilai budaya yang diuraikan di atas merupakan keseluruhan nilai-nilai yang kemungkinan muncul dan dapat ditemukan dalam masyarakat Nias. Melalui klasifikasi nilai-nilai budaya menurut Kluckhohn diharapkan dapat ditemukan dan diidentifikasi orientasi nilai-nilai luhur masyarakat Nias yang terkandung dalam syair-syair maena yang dituturkan dalam falöwa. Pemahaman terhadap nilai-nilai tersebut akan menunjukkan hakikat syair maena yang sesungguhnya dan menempatkan maena pada posisi yang seharusnya sebagai tradisi lisan yang bernilai tinggi.

Dalam memperoleh orientasi nilai budaya yang tepat dalam tradisi lisan maena, maka digunakan pendekatan antropolinguistik untuk memahami makna syair maena dalam konteks budaya masyarakat Nias. Antropolinguistik merupakan ilmu interdisipliner yang mengacu pada ilmu antropologi dan linguistik (Sibarani, 2015, hal. 2). Kedua ilmu tersebut dipadukan untuk memahami unsur dan struktur bahasa dalam ilmu linguistik dan menginterelasikannya dengan aspek perilaku manusia yang dapat ditemukan dalam kajian antropologi. Kajian antropolinguistik yang melibatkan bahasa dan kebudayaan sangat menekankan pada tiga aspek penting yaitu performansi (performance), indeksikalitas (indexicality), partisipasi (participation) (Duranti, 1997, hal. 14). Antropolinguistik bukan hanya mengkaji bahasa melainkan juga aspek-aspek yang berkaitan dengan tingkah laku dan kehidupan manusia.

Pendekatan antropolinguistik dapat digunakan dalam mengkaji tradisi lisan. Sebagaimana diketahui bahwa tradisi lisan terdiri atas perpaduan ekspresi linguistik 
dan aspek sosio-kultural yang menjadikannya sebagai objek kajian yang menarik dalam pendekatan antropolinguistik. Dalam penelitian ini, tidak hanya menjelaskan tentang penggunaan bahasa secara linguistik tetapi juga untuk mengungkap nilai budaya tradisi lisan maena secara antropologi.

Foley (2001) menjelaskan bahwa antropolinguistik berusaha mencari makna "meaning" di balik penggunaan bahasa dan sekaligus menjadi metode dalam memahami budaya. Konsep tersebut menunjukkan bahwa antropolinguistik terdiri atas tiga cakupan yakni aspek budaya, aspek linguistik dan aspek-aspek lain yang berkaitan dengan kehidupan manusia. Secara khusus dalam kajian tradisi lisan dengan pendekatan antropolinguistik menurut Sibarani (2015), terdiri atas (1) kajian tentang tradisi lisan yang menyangkut teks, koteks, dan konteks, (2) tradisi lisan yang berkaitan dengan makna dan fungsi, nilai dan norma, dan kearifan lokal, dan (3) revitalisasi dan pelestarian tradisi lisan. Ketiga bagian kajian tradisi lisan tersebut berdasarkan konsep parameter antropolinguistik, yaitu (1) keterhubungan (interconnection), (2) kebernilaian (valuability), (3) keberlanjutan (continuity). Penelitian tradisi lisan maena dengan pendekatan antropolinguistik ini melakukan pemahaman makna teks secara semantik, yang kemudian dihubungkan dengan unsur koteks dan konteks (sosial dan budaya) masyarakatnya sehingga dapat menginterpretasi sistem nilai yang ada dalam masyarakat Nias.

Berdasarkan latar belakang di atas, tujuan penelitian ini adalah mendeskripsikan orientasi nilai budaya masyarakat Nias dalam syair maena pada upacara adat falöwa di Gunungsitoli.

\section{B. METODE}

Penelitian ini menggunakan metode penelitian kualitatif dengan pendekatan antropolinguistik. Penelitian kualitatif merupakan penelitian yang menguraikan hasil bukan dalam bentuk angka namun dengan kata-kata. Umumnya penelitian kualitatif digunakan dalam penelitian terkait kehidupan masyarakat, tingkah laku, sejarah, aktivitas sosial, dan lain-lain. Penelitian kualitatif terdiri atas prosedur yang menghasilkan data deskriptif berupa kata-kata baik secara lisan maupun tulisan serta segala tingkah laku dari objek yang diamati (Bogdan et al., 1992). Penelitian kualitatif dengan pendekatan antropolinguistik yaitu dengan mengintegrasikan linguistik dan model etnografi komunikasi. Penelitian bahasa dilakukan dengan mengkaji data untuk memperoleh hasil deskriptif dengan menerapkan teori-teori linguistik. Sedangkan model etnografi komunikasi digunakan untuk memperoleh pola-pola komunikasi kelompok sosial. Melalui model etnografi komunikasi dilakukan kajian peranan bahasa dalam perilaku komunikasi dalam masyarakat. Peneliti melakukan penelitian langsung di lapangan untuk memperoleh pola dan penggunaan bahasa serta makna yang dihasilkan dari bahasa tersebut.

Adapun data dalam penelitian ini yaitu cuplikan syair maena pada upacara adat falöwa (pernikahan) baik dituturkan secara lisan dan kumpulan syair secara tertulis. Dalam penelitian ini, sumber data primer berupa wawancara dengan informan dan rekaman maena. Sedangkan sumber data sekunder berupa teks syair maena dalam buku "Maena Nias - Sarana Penyampaian Pesan dan Kisah Hidup Orang Nias" yang diterbitkan oleh Museum Pusaka Nias tahun 2018.

Data diperoleh dengan menerapkan dua metode pengumpulan data yakni metode simak dan metode cakap. Kedua metode tersebut merupakan metode pengumpulan data yang umum digunakan dalam penelitian bahasa. Metode simak 
menggunakan teknik sadap dan teknik lanjutan berupa teknik simak bebas libat cakap (SBLC). Dalam teknik sadap, peneliti melakukan kegiatan menyimak syair maena yang dituturkan oleh penutur maena. Selain teknik simak bebas libat cakap, teknik rekam digunakan sebagai teknik lanjutan untuk memudahkan peneliti dalam melakukan transkrip data.

Metode selanjutnya adalah metode cakap dengan menggunakan teknik cakap semuka, penelitian melakukan percakapan langsung atau wawancara dengan salah seorang anggota LBN (Lembaga Budaya Nias) di Gunungsitoli. Percakapan dilakukan menggunakan media komunikasi handphone (HP). Metode cakap digunakan untuk memperoleh informasi yang dapat mendukung keakuratan data penelitian.

Analisis data penelitian ini menggunakan metode Miles dan Huberman (Silalahi, 2009, hal. 339) dengan tahapan terdiri dari: reduksi data, penyajian data, dan penarikan kesimpulan/verifikasi. Kegiatan analisis ini terdiri dari tiga alur kegiatan yang terjadi secara bersamaan di mana reduksi data, penyajian data, dan penarikan kesimpulan sebagai suatu proses siklus dan interaksi pada saat sebelum, selama dan sesudah pengumpulan data dalam bentuk sejajar yang membangun wawasan umum. Dalam proses analisis data, peneliti juga melakukan validasi dengan menerapkan triangulasi data. Triangulasi yang digunakan dalam penelitian ini adalah triangulasi sumber yaitu dengan mengecek kembali kredibilitas atau tingkat keakuratan sebuah informasi yang diperoleh melalui dua atau lebih sumber yang berbeda (Sugiyono, 2008, hal. 274). Peneliti melakukan validasi terjemahan teks maena dan interpretasi yang sudah disusun oleh peneliti selanjutnya dicek ulang dan dibandingkan dengan analisis berdasarkan pemahaman informan untuk mendapat validitas.

\section{PEMBAHASAN}

Maena sebagai tradisi lisan yang sarat akan nilai-nilai luhur memiliki peranan penting dalam mengedukasi masyarakat Nias dalam berbagai aspek kehidupan. Nilai budaya yang ada dalam syair maena dapat dimanfaatkan untuk mengatur tatanan kehidupan masyarakat secara arif atau bijaksana. Melalui nilai dan norma dapat menjadi acuan atau panduan masyarakat dalam bertingkah laku (Sibarani, 2013, hal. 278). Syair-syair maena yang digunakan di dalam upacara adat falöwa di kota Gunungsitoli menunjukkan orientasi nilai budaya yang dijabarkan dalam lima hal dasar yang muncul dalam kehidupan manusia.

\section{Hakikat Hidup}

Hakikat hidup memberi pemahaman bahwa masing-masing budaya memiliki cara pandang yang berbeda dalam memaknai kehidupan. Keberagaman tersebut dapat diklasifikasikan dalam beberapa kategori antara lain: pada hakikatnya hidup manusia adalah buruk sehingga perlu dihindari, Adapun yang beranggapan bahwa hidup manusia pada dasarnya buruk namun manusia dengan segala usahanya dapat merubahnya menjadi baik. Dalam masyarakat Nias melalui syair maena menunjukkan pandangan dasar leluhurnya dalam memakanai hidup seperti pada syair berikut. 


\section{Data 1}

Mi bologö dödömi na lö hadöi sumangemi.

Me no arörö ndra'aga, meno arörö ndra'aga

Wangalui soguna.

\section{Gloss:}

Mohon maaf jika tidak ada sesuatu yang berharga yang dapat kami berikan sebagai bentuk penghormatan karena kami terlalu terpaku untuk memenuhi kebutuhan sehari-hari.

Syair pada data 1 merupakan syair maena yang disampaikan pihak dome (keluarga laki-laki) kepada pihak sowatö (keluarga) perempuan. Dalam syair tersebut mengandung majas litotes yang berusaha merendah diri di hadapan pihak tuan rumah. Dalam konteks budaya masyarakat Nias khususnya dalam acara adat pernikahan, pihak sowatö merupakan pihak yang disegani dan dikagumi terutama menjadi tumpuan harapan pihak dome. Bahkan dalam syair di atas pihak dome tidak hanya berusaha untuk merendahkan diri atau menunjukkan ketidakberdayaannya namun cuplikan lirik "meno arörö ndra'aga, wangalui soguna" memberikan penegasan bahwa mereka telah melakukan segala upaya dalam memenuhi kebutuhan hidup dalam hal ini juga termasuk memenuhi persyaratan yang diberikan pihak sowatö. Jujuran atau mahar berupa uang dan babi dalam adat Nias membutuhkan usaha yang besar dan tidak mudah bagi beberapa keluarga Nias tetapi keadaan tersebut tidak menjadi kendala dalam mencapai keinginan untuk mempersunting perempuan tambatan hati. Bagi masyarakat Nias, hidup perlu diperjuangkan, frasa "wangalui soguna" yang bermakna mencari penghidupan menunjukkan kegigihan dan upaya yang dilakukan dalam mencapai hidup yang baik dan yang dinginkan. Hakikat hidup dapat ditemukan dalam masyarakat Nias dan menunjukkan wujud nilai budaya masyarakatnya. Bagi suku Nias, hidup bukan hanya dipandang sesuatu hal yang buruk tetapi keadaan yang buruk dapat diubah menjadi sesuatu yang baik. Sikap optimisme dan keyakinan akan hasil usaha diyakini oleh masyarakat Nias untuk memahami makna hidup yang sesungguhnya.

\section{Hakikat Karya Manusia}

Dalam setiap kebudayaan memiliki pemahaman yang berbeda dalam memahami hakikat karya manusia, ada yang memandang karya manusia memiliki tujuan untuk meningkatkan nilai hidup namun ada pula kebudayaan yang menganggap hakikat karya manusia adalah untuk memberikan sebuah kedudukan dan kehormatan dalam masyarakat, selain kedua paham yang telah dijelaskan ada pula kebudayaan yang beranggapan bahwa karya manusia adalah sebuah pergerakan yang menuntut manusia untuk terus menghasilkan karya. Dalam syair maena yang dituturkan dalam upacara adat falöwa terdapat beberapa ungkapan yang merujuk pada pemahaman dan cara pandang masyarakat dalam memaknai sebuah karya manusia, seperti pada syair berikut. 


\section{Data 2}

Börö wa'atabö mbawimi, Ha börö wa'ebua gana'ami

Wa mitöröi mbanua mifasui

Ba wangalui somasi dödömi

\section{Gloss:}

Kalian memiliki ternak serta berkelimpahan harta

Hingga mampu bepergian jauh

untuk mendapatkan sesuatu yang kalian inginkan

Karya didefinisikan sebagai sebuah pekerjaan ataupun hasil perbuatan atau ciptaan. Definisi karya memiliki makna yang luas sehingga karya dapat juga dimaknai sebagai sebuah pencapaian seseorang dalam mencapai kemapanan secara materi. Syair maena dalam data (2) merupakan syair yang dituturkan pihak sowatö (keluarga perempuan) untuk menunjukkan kekaguman mereka terhadap keluarga dome. Cuplikan syair "Börö wa'atabö mbawimi, ha börö wa'ebua gana'ami" yang bermakna "karena ternak babi yang tambun dan banyaknya emas kalian", menegaskan dua unsur yang penting dalam adat pernikahan Nias dan merupakan komponen dalam jujuran atau mahar yaitu babi dan emas. Dalam konteks budaya pernikahan Nias hal paling utama dan penentu dalam melanjutkan kesepakatan keluarga perempuan dan laki-laki adalah kesepakatan nilai atau jumlah mahar yaitu babi dan emas (yang saat ini diganti dengan uang). Sehingga dapat dikatakan ketika seseorang telah memiliki dua hal tersebut, bahkan dalam syair di atas menjelaskan memiliki secara berkelimpahan maka dapat dikatakan mereka adalah keluarga yang patut dijunjung tinggi dan mampu mendapatkan apa saja yang mereka inginkan. Cuplikan syair berikutnya yang mengatakan "Wa mitöröi mbanua mifasui, ba wangalui somasi dödömi" yang artinya "bahkan kalian mengelilingi setiap kampung, untuk mencari dan menemukan sesuatu yang kalian inginkan" menunjukkan masyarakat Nias memahami bahwa seseorang yang memiliki harta kekayaan akan meningkatkan kedudukan dan kehormatannya di tengah-tengah masyarakat. Karya yang dimiliki dapat memudahkan dirinya juga dalam memperoleh segala sesuatu yang diinginkannya.

\section{Hakikat Kedudukan Manusia dalam Ruang dan Waktu}

Hakikat kedudukan manusia dalam ruang dan waktu dalam kebudayaan dipahami secara beragam, ada kebudayaan yang menganggap bahwa masa lampau sangat penting dalam kehidupan manusia dan menjadikan pengalaman dan peristiwa di masa lampau menjadi pedoman dalam menjalani kehidupan di masa depan. Sementara kebudayaan lain ada yang tidak mempersoalkan tentang masa lampau dan masa yang akan datang, yaitu mereka yang memiliki pandangan waktu yang sempit, atau sebaliknya ada pula yang berorientasi pada kehidupan di masa depan. Demikian pula masyarakat Nias memiliki pandangan tertentu dalam memahami kedudukan manusia dalam ruang dan waktu, dapat dilihat pada syair berikut: 


\section{Data 3}

Mitegu dania ndra'o e ndraono sangaoha-ngaoha

Lö lai zatua ebo-e no ebolo dödöra

\section{Gloss:}

Tegurlah aku saat aku bertingkah tidak baik dan tak peduli

Karena dulu orang tuaku masih sabar menghadapi sikapku.

Syair pada data 3 menunjukkan bahwa masyarakat Nias memandang bahwa masa lampau atau masa lalu seseorang akan mempengaruhi kehidupannya di masa yang akan datang. Syair maena di atas merupakan syair yang dituturkan oleh pihak sowatö sebagai pernyataan atau berupa pengakuan mewakili pengantin perempuan yang mungkin dikemudian hari ditemukan sikapnya yang tidak menyenangkan. Cuplikan syair "Mitegu dania ndra'o e ndraono sangaoha-ngaoha" yang berarti tegurlah aku saat aku tidak peduli atau acuh tak acuh, kalimat ini menunjukkan bahwa kebiasaan pengantin perempuan di masa lalu pasti akan terus melekat dalam dirinya bahkan ke mana pun dia akan pergi. Perubahan status seseorang tidak serta merta mengubah karakter dan kebiasaan seseorang sehingga penutur dalam hal ini memohon pengertian dan pemakluman dari pihak laki-laki. Selanjutnya, pada cuplikan bait "Lö lai zatua ebo-e no ebolo dödöra", yang bermakna "kalau orang tua pasti memakluminya" atau dapat juga diartikan "karena orang tuanya dulu selalu sabar menghadapinya". Memang dalam cuplikan syair tersebut tidak ada kata "dulu" atau yang menunjukkan masa lampau tetapi dikaitkan dalam konteks maka dimaknai bahwa orang tua yang dimaksud adalah orang tua perempuan.

Pernyataan cuplikan syair terakhir merujuk pada konteks budaya masyarakat dalam mendidik anaknya, sering kali anak perempuan masih diberikan ruang untuk bermanja-manja dan hanya melakukan apa saja yang mereka inginkan sementara orang tua lebih banyak sabar dan memakluminya. Keadaan tersebut bagi masyarakat Nias sesungguhnya akan menunjukkan gambaran keadaan manusia tersebut di masa depan. Melalui syair maena di atas dapat dipahami bahwa masyarakat Nias memandang manusia dipengaruhi oleh ruang dan waktu, apa yang terjadi di masa lampau harusnya dapat menjadi cerminan atau gambaran bagaimana seseorang tersebut nantinya di masa depan. Dalam konteks budaya, bagi masyarakat Nias dalam memilih jodoh juga perlu mempertimbangkan "bibit, bebet, dan bobot" calon pasangan karena ketiga aspek tersebut dapat dilihat bagaimana keadaan atau kondisi hubungan rumah tangganya di masa depan.

\section{Hakikat Hubungan Manusia dengan Alam Sekitarnya}

Hakikat hubungan manusia dengan alam sekitarnya, dalam kebudayaan tertentu yang meyakini kedahsyatan dan kekuatan alam sehingga manusia hanyalah makhluk yang pasrah atau hanya menerima apa pun yang terjadi. Sebaliknya kelompok budaya lain menganggap alam sebagai sesuatu yang harus ditaklukkan oleh manusia, dan ada pula budaya yang beranggapan bahwa manusia dan alam hakikatnya hidup berdampingan dan berusaha mencari keselarasan. Masyarakat Nias merupakan suku yang memiliki hubungan erat dengan alam, dapat dilihat dari segala aspek kehidupannya berhubungan dengan alam, begitu juga dalam acara adat falöwa. Beberapa komponen utama dalam upacara adat Nias adalah berasal dari alam, dan hal tersebut juga diungkapkan dalam syair maena berikut ini: 


\section{Data 4}

Tafaigi nösi mbo-e nösi mbola domeda

Ba te afo nifi-afo nifili ndra ina

\section{Gloss:}

Sepertinya ini adalah sirih terbaik yang dipilihkan oleh para ibu.

Jika dilihat dari isi kantong sirih yang diberikan para tamu

Syair pada data 4 merupakan syair yang disampaikan sowatö kepada pihak dome sebagai penghargaan atau apresiasi pengantin laki-laki menghantar sirih kepada ibu mertua. Syair di atas berupa pujian dan ungkapan senang pihak sowatö terhadap upaya yang dilakukan dome untuk menghormati dan menyenangkan hati sowatö. Dalam konteks budaya masyarakat Nias, sirih yang terdiri pinang, daun sirih, gambir, kapur sirih, dan tembakau merupakan komponen penting yang harus ada dalam kegiatan adat. Sirih bagi masyarakat Nias merupakan ungkapan penyambutan yang hangat dan tulus dalam hati. Sirih dalam upacara adat falöwa bukan hanya disediakan oleh pihak sowatö tetapi juga pihak dome (laki-laki). Dalam hal ini sebagai pihak yang sedang berupaya untuk menyenangkan hati keluarga perempuan yang dipersuntingnya, pihak laki-laki harus membawa sirih yang terbaik untuk diberikan kepada keluarga calon istrinya. Keberadaan "sirih" sebagai unsur penting di dalam adat Nias menunjukkan hubungan masyarakat Nias terhadap alam sekitarnya. Masyarakat Nias dan alam sekitarnya memiliki hubungan saling bergantung dan hidup berdampingan serta ditemukan keselarasan di antara alam dan manusianya.

\section{Hakikat Hubungan Manusia dengan Sesamanya}

Hakikat hubungan manusia dengan sesamanya di beberapa kebudayaan memiliki pandangan yang berbeda, ada kebudayaan memandang hubungan vertikal antara manusia dengan sesamanya sangatlah penting. Tokoh-tokoh, pemimpin atau seseorang yang memiliki pengalaman dan wawasan luas menjadi panutan mereka dalam bertingkah laku atau bersikap dengan sesama. Ada juga kebudayaan yang menganggap hubungan horizontal antara sesama jauh lebih penting, yakni antar sesama manusia memiliki posisi yang sama dan saling bergantung satu sama lain. Kedua paham sebelumnya merupakan padangan yang masih mengakui hakikat hubungan antara manusia, namun selain kedua pandangan tersebut ada pula kebudayaan yang tidak membenarkan adanya hubungan antara manusia dengan manusia lainnya. Pandangan ini menganggap manusia tidaklah tergantung pada orang lain melainkan setiap manusia harus hidup mandiri dan mencapai tujuan hidupnya tanpa bantuan atau hubungan dengan orang lain. Masyarakat Nias sangat menjunjung tinggi hubungan manusia dengan manusia lainnya. Bahkan fondrakö yang merupakan pedoman hidup suku Nias dalam berbudaya dan bermasyarakat didasari pada prinsip masi-masi atau kasih sayang. Hal tersebut berarti para leluhur masyarakat Nias pun telah memiliki pandangan yang jelas tentang hakikat hubungan antar manusia. Hakikat hubungan antara manusia dalam masyarakat Nias dapat dilihat dari syair berikut: 


\section{Data 5}

Hadia wamaedo khöda duma-duma, ba me orudu faondra sa falukha

\section{Gloss:}

Tak ada yang lebih berharga dan menyenangkan

dibanding perjumpaan dalam kebersamaan

Syair pada data 5 merupakan syair yang dituturkan oleh pihak sowatö kepada pihak dome yang mengungkapkan rasa sukacita dengan keinginan paling terdalamnya adalah kebersamaan. Cuplikan lirik "Hadia wamaedo khöda duma-duma" yang bermakna tak ada yang lebih berharga dan menyenangkan adalah sebuah kalimat yang mendeskripsikan sesuatu berupa objek atau kondisi yang tak ternilai harganya dan hal yang dimaksudkan itu adalah perjumpaan "orudu faondra." Syair di atas menunjukkan bahwa masyarakat Nias memandang interaksi atau menjalin hubungan dengan sesama merupakan hal yang penting dan yang paling berharga. Dalam konteks budaya, masyarakat Nias sangat menjunjung tinggi hubungan kekerabatan. Khususnya dalam pesta pernikahan "falöwa" rangkaian adat istiadat yang berlangsung selalu melibatkan kedua pihak yaitu pihak dome dan sowatö hal tersebut tentu bertujuan untuk mempererat hubungan kekeluargaan. Hubungan tersebut dapat dikategorikan sebagai hubungan horizontal yang memandang hubungan antar manusia adalah saling bergantung dan saling membutuhkan.

\section{PENUTUP}

Berdasarkan hasil dan pembahasan dalam penelitian di atas ditemukan bahwa maena dalam masyarakat Nias tidak hanya sekedar pertunjukkan tarian namun memiliki kekuatan pada syair-syairnya. Syair maena yang dituturkan dalam setiap upacara falöwa di Kota Gunungsitoli memiliki orientasi nilai-nilai budaya. Berdasarkan hal tersebut disimpulkan bahwa, pertama, masyarakat Nias memaknai hakikat hidup sebagai sesuatu hal yang perlu diperjuangkan. Hidup yang buruk dapat diubahkan menjadi baik jika ada upaya dari manusianya. Kedua, masyarakat Nias memandang hakikat dari karya dapat meningkatkan kedudukan dan kehormatan manusia dalam lingkungannya. Seseorang yang memiliki karya akan mendapatkan apresiasi serta penghargaan oleh orang lain dan hal tersebut juga akan memudahkan seseorang untuk mendapatkan apa yang diinginkannya. Ketiga, masyarakat Nias memandang bahwa manusia dipengaruhi oleh ruang dan waktu. Pengalaman dan kebiasaan manusia di masa lampau akan menunjukkan gambaran kehidupannya di masa depan. Keempat, masyarakat Nias memandang pentingnya keselarasan hubungan manusia dan alam sekitarnya. Keduanya memiliki hubungan saling bergantung dan hidup berdampingan. Kelima, masyarakat Nias menjunjung tinggi hubungan manusia dengan sesamanya. Dalam hal ini hubungan vertikal lebih terlihat jelas yaitu hubungan di mana antar manusia merasa saling membutuhkan. 


\section{DAFTAR PUSTAKA}

Bogdan, Robert, \& Taylor. (1992). Pengantar Metode Penelitian Kualitatif. Terjemahan oleh Arief Rurchan. Surabaya: Usaha Nasional.

Duranti, A. (1997). Linguistic Anthropology. New York: Cambridge University Press. http://library1.nida.ac.th/termpaper6/sd/2554/19755.pdf

Foley, W. A. (2001). Anthropological Linguistics: An Introduction (Vol. 53, Issue 9). Blackwell Publishers Ltd.

Hämmerle, J. M., Halawa, A., Nduru, H., \& Giawa, R. T. (2018). Maena Nias: Sarana Penyampai Pesan dan Kisah Hidup Orang Nias. Gunungsitoli: Yayasan Pusaka Nias.

Kartikasari, E. (2021). Nilai Budaya dalam Serat Ajisaka. Diglosia: Jurnal Kajian Bahasa, Sastra, Dan Pengajarannya, 4(2), 177-188. https://doi.org/10.30872/diglosia.v4i2.139

Kluckhohn, F. R., \& Strodtbeck, F. L. (1961). Variations in Value Orientations. Evanston, Illinois: Row, Peterson.

Koentjaraningrat. (2002). Pengantar Ilmu Antropologi. Jakarta: Djambatan.

Levi-Strauss, C. (1963). Structural Anthro-po-logy. New York: Basic Books.

Mendrőfa, S. W. (1981). Fondrakő Ono Niha: Agama Purba-Hukum Adat-MitologiHikayat Masyarakat Nias. Jakarta Raya: Inkultra Foundation Inc.

Muhni, D. I. (1994). Moral dan Religi menurut Emile Durkheim dan Henri Bergson. Kanisius.

Mujib, A. (2009). Hubungan Bahasa dan Kebudayaan. Adabiyyāt: Jurnal Bahasa Dan Sastra, 8(1), 141-154.

Sibarani, R. (2015). Pendekatan Antropolinguistik Terhadap Kajian Tradisi Lisan. RETORIKA: Jurnal Ilmu Bahasa, 1(1), 1-17. https://doi.org/10.22225/jr.v1i1.9

Sibarani, R. (2013). Pendekatan Antropolinguistik dalam Menggali Kearifan Lokal Sebagai Identitas Bangsa. Prosiding The 5th International Conference on Indonesian Studies: "Ethnicity and Globalization," 274-290.

Silalahi, U. (2009). Metode Penelitian Sosial. Bandung: PT. Refika Aditama.

Sugiyono. (2008). Metode Penelitian Kuantitatif Kualitatif dan R\&D. Bandung: Alfabeta.

Suwartiningsih, S., \& Samiyono, D. (2014). Harmoni Sosial: Kearifan Lokal masyarakat Nias. Jurnal Societas Dei, 1(1), 235-269.

Wardaugh, R. (2006). An Introduction to Sociolinguistics. The British Journal of Sociology, 38(3). https://doi.org/10.2307/590702

Zaluchu, S. E. (2020). Deskripsi Tarian Maena sebagai Identitas Suku Nias. Nyimak: Journal of Communication, 4(1), 135-147. http://jurnal.umt.ac.id/index.php/nyimak/article/view/2219 